\title{
PERIPHERAL PLASMA CONCENTRATIONS OF PROGESTERONE, OESTRADIOL-17 $\beta$ AND LUTEINIZING HORMONE AROUND OESTRUS IN THE COW
}

\author{
M. LEMON, J. PELLETIER, J. SAUMANDE AND J. P. SIGNORET \\ I.N.R.A.-Laboratoire de Physiologie de la Reproduction, Nouzilly, \\ 37380 Monnaie, France
}

(Received 29th May 1974)

The concentrations of a number of reproductive hormones found in the peripheral plasma of the cow around the time of oestrus have been measured by numerous authors: plasma concentrations of progesterone throughout the oestrous cycle (Stabenfeldt, Ewing \& McDonald, 1969), LH (Schams \& Karg, 1969), oestrogen and progesterone (Henricks, Dickey \& Hill, 1971) and LH and progesterone (Henricks, Dickey \& Niswender, 1970). These and other reports have paid little attention to the precise onset and duration of oestrus, behaviour being checked at various intervals (usually two or three times a day) before the expected onset.

To obtain a more precise pattern of hormone concentrations around oestrus, we have measured simultaneously $\mathrm{LH}$, oestradiol-17 $\beta$ and progesterone in samples of plasma taken at 2-hr intervals from cows over a period of 5 days. The cows were maintained with a bull, to allow continuous observation of sexual behaviour. By such observation, we have attempted to define the true onset of oestrus, to dissociate it from preliminary pro-oestrous behaviour and to correlate the behavioural manifestations of oestrus with the internal hormonal parameters. This preliminary study was intended to establish hormonal criteria in the normal cyclic cow for later comparison with animals undergoing treatment for synchronization of oestrus, when administration of exogenous hormones might modify the endogenous hormone balance, and when a decrease in fertility often results.

Blood samples were collected from the jugular vein of four cyclic, multiparous Friesian cows, at intervals of $2 \mathrm{hr}$ for a period of 5 days, starting on Day, 18 of the cycle (day of oestrus = Day 0 ). Daily blood collections were made for several days before this, and until Day 10 of the following cycle. Plasma was separated by centrifugation and stored at $-20^{\circ} \mathrm{C}$ until assay. The four cows were maintained in a yard with a sexually experienced, vasectomized bull during the period of 2-hr blood collections. The patterns of sexual behaviour were recorded by continuous observation, noting every interaction of an experimental cow with the bull or with another cow (sniffing, licking, placing the head on the other animal's hindquarters, mounting). A female was con- 
sidered sexually receptive if she stood still when mounted by another animal, and the duration of oestrus was estimated as the period of time elapsing between the first and the last positive reaction. Some hours before the onset of oestrus, a number of patterns of sexual activity were recorded. Since these activities were rejected by the experimental female, this period was regarded as the prooestrous period.

The concentration of progesterone in the duplicate 1-ml plasma samples was estimated by the competitive protein-binding technique described by Bassett \& Hinks (1969) and Thorburn, Bassett \& Smith (1969), and results were corrected for procedural losses. Oestradiol-17 $\beta$ and LH were both measured by radioimmunoassay: oestradiol-17 $\beta$ by the method of Terqui, Dray \& Cotta (1973), and LH using the technique described in detail by Pelletier (1972).

Of the four cows used in the study, three came into oestrus within 3 days after the beginning of $2-\mathrm{hr}$ blood sampling. The duration of sexual receptivity in these three cows was $7 \cdot 3,10$ and $15 \mathrm{hr}$, whereas the duration of the prooestrous period ranged from 0 to $13 \mathrm{hr}$. These results, and those of the hormone assays are shown in Text-fig. 1. The time between progesterone reaching low concentrations $(<0.5 \mathrm{ng} / \mathrm{ml})$ and the onset of oestrus varied from 28 to $40 \mathrm{hr}$, and no pro-oestrous progesterone rise was observed, contrary to a report by Ayalon \& Shemesh (1974). Our assay was tested for specificity and was sensitive to $0.08 \mathrm{ng} / \mathrm{ml}$. Before the onset of oestrus, no clear-cut oestradiol peak was found, but a series of peaks of fluctuating concentration, with an overall increase in their maxima to around $25 \mathrm{pg} / \mathrm{ml}$. The maximum concentrations of oestradiol-17 $\beta$ varied in the time at which they occurred in relation to the onset of oestrus: this observation has since been confirmed in a similar experiment with a large number of normal cyclic cows (J. Saumande, unpublished results), in which maximum concentrations occurred either before, at the same time, or after the onset of oestrus. In two cows (Nos 620 and 645), the oestradiol concentration began to rise above basal levels of around 10 $\mathrm{pg} / \mathrm{ml}$ at the time when progesterone began to decrease. Plasma LH increased from 2 to $4 \mathrm{ng} / \mathrm{ml}$ to a peak of 30 to $35 \mathrm{ng} / \mathrm{ml}$ and decreased again to basal levels over a period of 10 to $12 \mathrm{hr}$. There was almost perfect synchronization of the beginning of the LH peak with the onset of sexual receptivity in the three cows (Text-fig. 1).

In the one cow which did not show oestrous behaviour, luteal regression began on Day 19, later than in the other cows. Concentrations of LH remained low, with no evidence of a discharge, and there was no relationship between the decrease in progesterone and the increase in oestradiol concentrations. The concentrations of oestradiol were relatively high when those of progesterone were still elevated, and later progressively decreased to basal levels.

Our results agree with those already reported by other authors for the cow, and provide a more precise indication of the simultaneous variations in the plasma concentrations of progesterone, oestradiol- $17 \beta$ and $\mathrm{LH}$ during the pro-oestrous and oestrous periods. Oestradiol seems to be clearly involved in the discharge of $\mathrm{LH}$, but only when progesterone has decreased to low levels. This finding is supported by the results of Glencross, Munro, Senior \& Pope (1973), who observed that when progesterone remains high as a result of 


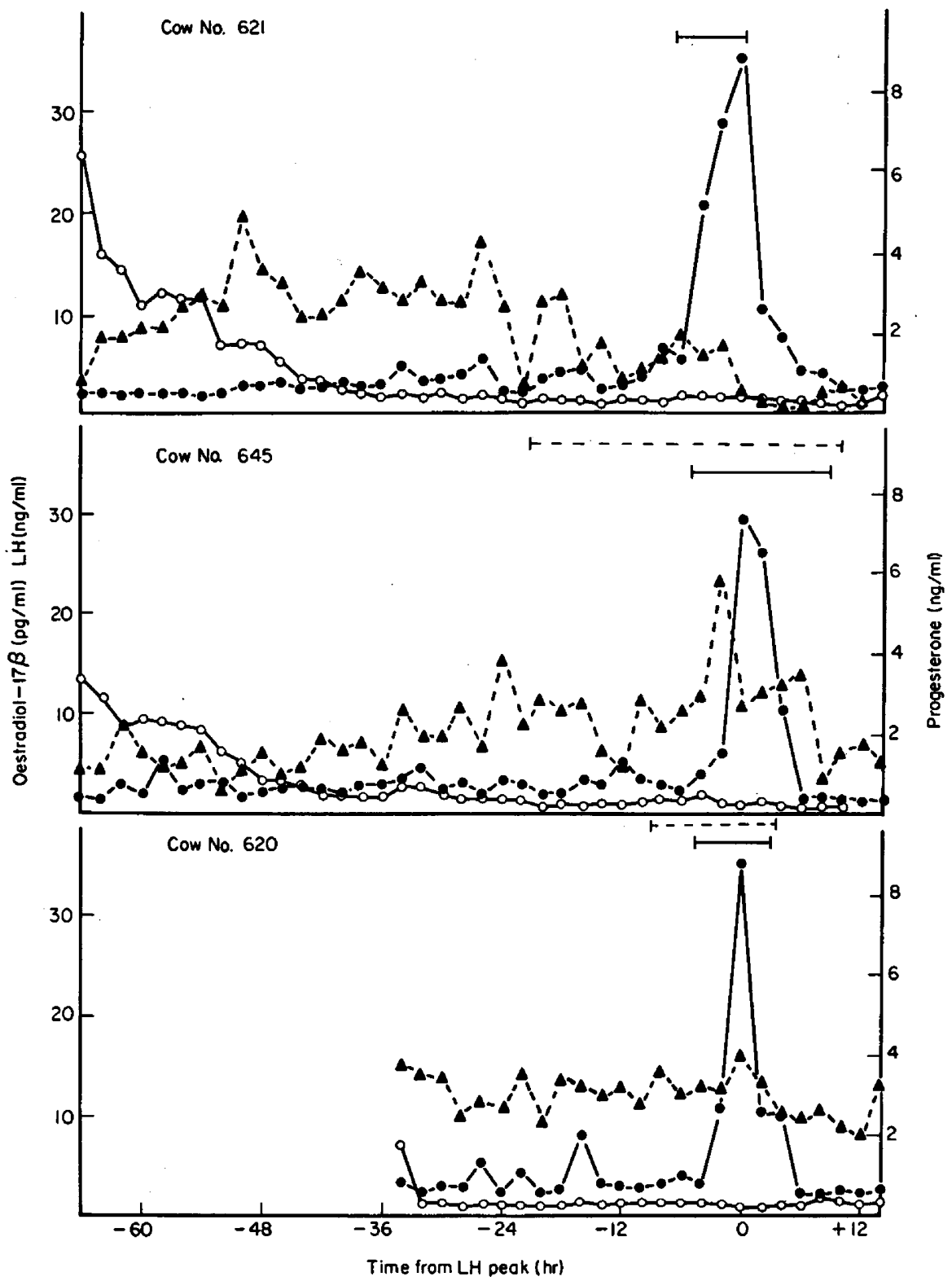

Text-Fig. 1. Concentrations of progesterone (O), oestradiol-17 $\beta$ ( $\Delta$ ) and LH (O) measured in peripheral plasma taken at 2 -hr intervals from three cows around the time of oestrus. All values are the means of duplicate determinations. The duration of sexual receptivity is indicated by the solid line ( -$)$ and the total duration of all sexual activity by the broken line (......) 
conception in the cow a rise in oestradiol concentration occurs as it would have done before ovulation.

A correlation between sexual receptivity and the LH peak was suggested by Cummins, Blockey, Brown \& Goding (1972). Although the present study was carried out with a sample of limited size, our results show a very close association between these criteria. These results stress the importance of associating endocrinological studies with accurate observations of behavioural variations.

We wish to thank Dr L. E. Reichert, who kindly supplied the bovine LH (LER-1072-2) for the LH assay, and Mr M. de Reviers for his assistance with the calculation of the results of the oestradiol assay.

\section{REFERENGES}

Axalon, N. \& Shemesh, M. (1974) Pro-oestrous surge in plasma progesterone in the cow. F. Reprod. Fert. 36, 239-243.

BassetT, J. M. \& Hinks, N. T. (1969) Micro-determination of corticosteroids in ovine peripheral plasma: effects of venipuncture, corticotrophin, insulin and glucose. F. Endocr. 44, 387-403.

Gummins, L. J., Blockey, M. A. de B., Brown, J. M. \& Goding, J. R. (1972) A study of luteinizing hormone secretion in the cow. 7. Reprod. Fert. 28, 135, Abstr.

Glencross, R. G., Munro, I. B., Senior, B. E. \& Pope, G. S. (1973) Goncentrations of oestradiol-17 $\beta$, oestrone and progesterone in jugular venous plasma of cows during the oestrous cycle and in early pregnancy. Acta endocr., Copenh. 73, 374-384.

Henricks, D. M., Dickey, J. F. \& Hill, J. R. (1971) Plasma estrogen and progesterone levels in cows prior to and during estrus. Endocrinology, 89, 1350-1355.

Henricks, D. M., Dickey, J. F. \& Niswender, G. D. (1970) Serum luteinizing hormone and plasma progesterone levels during the estrous cycle and early pregnancy in cows. Biol. Reprod. 2, 346-351.

Pelletier, J. (1972) Dosages radioimmunologiques de la LH plasmatique ovine et bovine. In Techniques Radioimmunologiques, p. 237. Colloque Inst. nat. Sante Rech. med. Paris. INSERM, Paris.

Schams, D. \& KARG, H. (1969) Radioimmunologische LH-bestimmung in Blutserum von Rind unter besonderer Berücksichtigung des Brunstzyklus. Acta endocr., Copenh. 61, 96-103.

Stabenpeldt, G. H., Ewing, L. L. \& MaDonald, L. E. (1969) Peripheral plasma progesterone levels during the bovine oestrous cycle. F. Reprod. Fert. 19, 433-442.

Terqu, M., Dray, F. \& CotTa, J. (1973) Variations de la concentration de l'oestradiol-17 $\beta$ dans le sang périphérique de la Brebis au cours du cycle oestral. C. r. hebd. Séanc. Acad. Sci., Paris, 277, 1795-1798.

Thorburn, G. D., Bassetr, J. M. \& Smrth, I. D. (1969) Progesterone concentration in the peripheral plasma of sheep during the oestrous cycle. $\mathcal{F}$. Endocr. 45, 459-469. 